\title{
AIDS and Cancer Specimen Bank
}

National Cancer Institute

\section{Source}

National Cancer Institute. AIDS and Cancer Specimen Bank. NCI Thesaurus. Code C16195.

The ACSB provides qualified researchers with tissue, cell, blood and fluid specimens, as well as clinical data from patients with HIV-related malignancies. The ACSB contains formalin-fixed paraffin embedded tissues, fresh frozen tissues, malignant cell suspensions, fine needle aspirates, and cell lines from patients with HIV-related malignancies. The bank also contains serum, plasma, urine, bone marrow, cervical and anal specimens, saliva, semen and multi-site autopsy tissues from patients with HIVrelated malignancies including those who have participated in clinical trials. The bank has an associated database that contains prognostic, staging, outcome and treatment data on patients from whom tissues were obtained. (CancerNet) 